\title{
Competitiveness of Russian Economy: Evaluation and Development Prospects
}

Tatyana Anatolyevna Salimova

Ogarev Mordovia State University, Saransk, Russian Federation

Nadezda Dmitrievna Gouskova

Ogarev Mordovia State University, Saransk, Russian Federation

Ivan Alexandrovich Gorin

Ogarev Mordovia State University, Saransk, Russian Federation

Yuliana Yurevna Slushkina

Ogarev Mordovia State University, Saransk, Russian Federation

Correspondence: Kommunisticheskaya st., h.10, ap.112,

Doi:10.5901/mjss.2015.v6n3s3p55

430005, Saransk, Republic of Mordovia, Russian Federation

\section{Abstract}

The paper analyzes causes of low competitiveness of economy and deterioration of main socioeconomic indicators of Russia at the beginning of the 90s of the 20th century. The analysis of the most authoritative ratings in the area of global competitiveness is carried out: methods of World Economic Forum and International Institute for Management Development, and the corresponding place of Russia over the period from 2009 to 2014 is determined. Findings are compared to conclusions by the level of business activity (Doing Business rating) - a research carried out by World Bank and International Finance Corporation. Data of all three independent rating researches confirm considerable strengthening of Russian position over last 5 years. In the course of the research it was found that there is a direct correlation between the competitiveness growth of Russia and high prices for raw hydrocarbons. In the course of the research direct dependence between price for oil and the number of consumed imported products and services in the country, and the absence of direct correlation between prices for hydrocarbons and investments in fixed capital were revealed. Based on trend method the authors conclude an increase in Russian economy competitiveness in years to come in the absence of strong external constraints. Further the researchers suggest ways of stabilization and sustainable development.

Keywords: global competitive ability, import substitution, economic development, crisis, economic sanctions, country rating.

\section{Introduction}

The development of international economic relations under conditions of globalization is characterized by international integration and experience of synergetic effect from this process by each country; standardization and harmonization of legal and economic relations, technology and communications; regulation of food stuff and environment safety ensuring standards, etc.

In our opinion, Russian government made a number of mistakes in formation international relations and internal policy at the beginning of the 90 s of the $20^{\text {th }}$ century. External and internal policy were focused not on improvement of the quality of the Russians' life in the future, competitive growth of goods, services, enterprises and the country in general, growth in exports of science-intensive products, but on accelerated break with all values (culture, moral, intellectual and production potential, etc.), accelerated liberalization of all spheres of activity from the USA experience, on accelerated privatization to IMF recipes, etc.

Results of these reforms were considerable rating downgrade of global competitiveness, and, consequently, decrease in GDP of the country, degradation of some economic branches (consumer industry, machinery manufacturing, etc.), credit rating downgrade, etc. that has had a significant impact on the living standards of nationals of Russia. The Russian Federation ranked low not only regarding competitiveness and living standards but resource use efficiency (2-3 times lower than in developed countries), investment climate, replacement of fixed assets, reproduction of population, etc. 
In our opinion, main causes of poor competitiveness and deterioration of major social and economic indicators of Russia at the beginning of the $90 \mathrm{~s}$ of the $20^{\text {th }}$ century are the following:

- accelerated liberalization, privatization, and "stabilization" according to recipes of IMF, touting Russia the "Washington Consensus" of shift to market relations (Lvov D., 2001);

- destruction of science (Lvov D., 2001; Fedorenko N., 2001, and others);

- since 1992 shift to humanitarian system of economists' training, managers training using Western textbooks written in a philosophical historical manner relevant for conditions of established market relations;

- waiving strategic planning institute at all levels of management (while planning quality increases in developed countries, for example, in the USA, Japan, France, Korea, and others);

- in the beginning of the $90 \mathrm{~s}$ of the $20^{\text {th }}$ century governmental waiving development of complex strategy of country shift to market relations and problem strategies over a long-term perspective;

- the absence of transitional economy theory consisting in the "visible hand" of governmental regulation, invisible hand of the market and mechanism of global competition in the context of accession to the WTO;

- very slow implementation of strategic marketing conception and activity focus on competitiveness of objects under regulation, resource conservation and improvement of nation's living standards into the system of higher education;

- low quality (feasibility, reliability) of management decisions, especially strategic ones.

\section{Literature Review}

To the present day the issue concerning methodological problems of global competitiveness measurement and distinguishing major components constituting its content and its influencing factors isn't completely explored. At the same time, individual aspects at the level of national economies and their competitive capabilities, their increase strategies are explored much less. Representatives of the classical school of political economy Smith A. (Smith A., 1776) и Ricardo D. (Ricardo D., 1817) are considered founders of competition theory basics, although there were attempts to create a general idea of competition in the period of mercantilists. Further their ideas were developed in the works of Schumpeter J. (Schumpeter J., 1934), Solow R. (Solow R., 1956), Drucker P. (Drucker P., 1981). The papers of Porter M. (Porter M., 1990), Lindert P. (Lindert P., 1986), Williamson J. (Williamson J., 1989), Mill J. (Mill J., 1848), Rogoff K. (Rogoff K., 2009) are considered fundamental works describing methodological matters of international competitiveness in a complex way. Key dependences and cause-and-effect relations concerning individual questions of international competitiveness were covered in the works of such scientists as Keynes J. (Keynes J., 1919), Galbraith J. (Galbraith J., 1975), Krugman P. (Krugman P., 1999), Brue S. ( Brue S., 2014), McConnell C. (McConnell C., 2014), Marshall A. (Marshall A., 1879), Fisher I. (Fisher I., 1906).

Foreign experience was taken as a basis for theoretical developments of Russian scientists relating to issues of increase in competitive capability, globalization development and scientific and technical progress and their influence on economy, directly influencing the theory on global competitiveness. Among them there are works of such researchers as Azoev G. (Azoev G., 2002), Baumgarten L. (Baumgarten L., 2005), Bogomolov, I. (Bogomolov I., 2005), Voronov A. (Voronov A., 2000), Gelvanovsky M. (Gelvanovsky M., 1998), Goncharov N. (Goncharov N., 1998), Zakharchenko V. (1999), Ivanetc V. (Ivanetc V., 2000), Litvinenko V. (Litvinenko V., 1993), Lifits I. (Lifits I., 2004), Mansurov R. (Mansurov R., 2006), Ostrovsky G. (Ostrovsky G., 2001), Seleznev A. (Seleznev A., 1999), Sinko V. (Sinko V., 2001), Shekhovtseva L. (Shekhovtseva L., 2001), Yudanov A. (Yudanov A., 1996), Yanovsky A. (Yanovsky A., 1997) and others.

\section{Methodology}

Evaluation of country competitiveness level and determination of its development prospects is one of economists' main tasks. There are many estimation techniques of global competitiveness level. Two of them are of the greatest interest: methods of World Economic Forum and International Institute for Management Development.

The analysis of global competitiveness rating of World Economic Forum shows that Switzerland ranks first over the last 6 years. Singapore and the USA rank second and third correspondingly over 2013-2015. It makes sense to compare the place of Russia in the system of global competitiveness to countries of the similar level of national economies' development - BRICS countries. Among them China takes the lead - the $28^{\text {th }}$ place (as of 2014/2015). The Republic of South Africa and Brazil rank 56 and 57 correspondingly, India ranks 71. Previously Russia gave way to all BRICS countries, but for the last year it raised from the $64^{\text {th }}$ to $53^{\text {th }}$ place due to improvements relating to goods and services market efficiency, the use of information and communication technologies, and competitive capability of companies. WEF 
experts point out the following competitive advantages of the Russian Federation: high level of population's education and large innovation potential. Balanced macroeconomic indicators made major contribution to improvement of current positions of Russia: low level of government debt, higher education wide coverage, annual budget surplus, considerable domestic market size. At the same time, the following negative trends were revealed: low efficiency of public institutions operation, ineffective antimonopoly policy, immaturity of financial market, etc. It should be also mentioned that report was made before imposing sanctions by Western countries, their influence in rating indicators wasn't considered. Mentioned negative factors suppress Russian promotion in WEF rating (Table 1).

Table 1 - Positions of Russia in global competitiveness rating of World Economic Forum*

\begin{tabular}{|l|c|c|c|c|c|c|}
\hline \multirow{2}{*}{ Indicator } & \multicolumn{5}{|c|}{ Years } \\
\cline { 2 - 7 } & $2009 / 2010$ & $2010 / 2011$ & $2011 / 2012$ & $2012 / 2013$ & $2013 / 2014$ & $2014 / 2015$ \\
\hline The number of countries in the rating & 133 & 139 & 142 & 144 & 148 & 144 \\
\hline Russia's place & 63 & 63 & 66 & 67 & 64 & 53 \\
\hline
\end{tabular}

WEF Global Competitiveness Reports, 2009-2014.

The rating analysis of International Institute for Management Development (IMD) by the level of global competitiveness is calculated according to other methods than WEF's. Thus, the number of indicators in the rating is 300 . They are singled out by four main areas: macroeconomic situation, public administration bodies efficiency, business environment efficiency, and infrastructure quality. Each direction includes five key factors and has equal weight when calculating final result. In comparison with WEF rating, IMD yearbook rates much less countries (as of 2014 - 60). These countries are largely represented by major countries of OEDC and major countries with economies in transition. Rating is carried out based on the following formula: about $70 \%$ fall at statistical data (harddata) and about $30 \%$ at expert evaluations. According to IMD in 2014 the USA became the world leader by the level of global competitiveness dominating in the area of economy and infrastructure, while Asian financial centers got high scores for government work and business conduct efficiency. The USA is followed by Switzerland and Singapore. Hong Kong, Sweden, Germany, Canada, the United Arab Emirates, Denmark, and Norway entered top 10 of the most competitive economies.

According to IMS competitiveness of Russia over the last 6 years has increased that allowed the country to rise from the $49^{\text {th }}$ place in 2009 to $36^{\text {th }}$ in 2014 (Table 2), advancing some European countries (Spain $-3^{\text {th }}$ place, Italy $-46^{\text {th }}$ place). Researchers consider high level of education and employment, man power qualification and general stability of economy the main drivers of Russian competitiveness growth. Rating's authors mention low level of economic diversity and labour productivity, low sensitivity to innovations and low efficiency of public management, including administrative barriers and corruption, among main adverse factors defining competitiveness of Russia.

Table 2 - Positions of Russia in the global competitiveness rating of International Institute for Management Development

\begin{tabular}{|l|c|c|c|c|c|c|}
\hline \multirow{2}{*}{ Indicator } & \multicolumn{7}{|c|}{ Years } \\
\cline { 2 - 8 } & 2009 & 2010 & 2011 & 2012 & 2013 & 2014 \\
\hline The number of countries in the rating & 57 & 58 & 59 & 59 & 60 & 60 \\
\hline Russia's place & 49 & 51 & 49 & 48 & 42 & 36 \\
\hline Macroeconomic situation & 49 & 49 & 42 & 45 & 34 & 41 \\
\hline State efficiency & 39 & 40 & 46 & 45 & 43 & 37 \\
\hline Business environment efficiency & 54 & 53 & 54 & 53 & 53 & 53 \\
\hline Infrastructure quality & 38 & 38 & 38 & 38 & 39 & 35 \\
\hline
\end{tabular}

IMD World Competitiveness Yearbooks, 2009-2014

Together with two given authoritative ratings of global competitiveness, practice-oriented annual joint research carried out by World Bank and International Finance Corporation entering the group of WM - Doing Business - is of interest for the analysis. In the context of the research monitoring and evaluation of administrative practice, and also changes introduced to regulatory framework that regulates activity of organizations and enterprises, mainly small and medium-sized ones, throughout their life cycle are carried out.

The rating of Doing Business is carried out based on 10 indicators, such as setting-up of companies, property registration, taking loans, taxation, etc. In final rating all countries are ranged by the rating of easiness of business conduct from the $1^{\text {st }}$ to the $189^{\text {th }}$ place (in 2014). All 10 indicators in the rating are of the same weight. Following the results of the integral value of Doing Business Singapore ranks first seventh years at a run. It should be noted that in this 
country reforms aimed at improvement of business conduct conditions are carried out successively. The first five of leading countries are the same over the last years: Singapore, Hong Kong, New Zealand, the USA, and Denmark.

Over the last year Russia considerably improved its positions, rising from the $112^{\text {th }}$ to the $92^{\text {th }}$ place. Conditions of business conduct were improved by 5 from 10 indicators, moreover, the results of new report appeared to be the best for the Russian Federation over the record history. At the same time, it should be noted although this rating is made for a country in general, data of statistics on Russia that were used in it, were compiled only by two federal cities - Moscow and St. Petersburg and 2 regions - the Moscow and the Leningrad regions.

Table 3 - Change of place of Russia in ratings of Doing Business of World Bank

\begin{tabular}{|l|c|c|c|c|c|}
\hline \multirow{2}{*}{ Indicator } & \multicolumn{5}{|c|}{ Years } \\
\cline { 2 - 6 } & 2010 & 2011 & 2012 & 2013 & 2014 \\
\hline The number of countries in the rating & 183 & 183 & 183 & 185 & 189 \\
\hline Russia's place & 120 & 123 & 120 & 112 & 92 \\
\hline
\end{tabular}

Doing Business database

In the rating of Doing Business following the results of 2014 the positions of BRICS countries are the following: China the $96^{\text {th }}$ place, Brazil - the $116^{\text {th }}$ place, and India- the $134^{\text {th }}$ place. While countries of the Eurasian Customs union Kazakhstan and Belarus held $50^{\text {th }}$ and $63^{\text {th }}$ places, Ukraine - the $112^{\text {th }}$ place.

If we carry out analysis among indicators used in Doing Business rating by Russia, criteria "securing execution of contracts" - the $10^{\text {th }}$ place and "property registration" - the $17^{\text {th }}$ place in the world took the highest values. Least values "international trade" - the $157^{\text {th }}$ place and "obtaining building license" - the $178^{\text {th }}$ place from 189 countries (Table 4).

Table 4 - "Business conduct - 2014": positions of Russia

\begin{tabular}{|c|c|c|c|c|c|c|c|c|c|c|c|}
\hline Country & Final rating & No. 1 & No.2 & No.3 & No.4 & No.5 & No.6 & No.7 & No.8 & No.9 & No.10 \\
\hline Russia & 92 & 88 & 178 & 117 & 17 & 109 & 115 & 56 & 157 & 10 & 55 \\
\hline
\end{tabular}

Let's reduce data of three ratings to a common base in order to analyze how situation regarding competitiveness and business conduct conditions has been changing in Russia over the last 5 years.

Let's develop a simple procedure for detecting a trend for Russia. Since we assume that the notion of "competitiveness" is "an ability to compete under current conditions", it's sufficient to reduce competitiveness level in comparison with competitors in order to measure it. In this case these are other countries included in rating. In order to define direction of trend it's necessary to divide place of Russia in rating into the number of participating countries. As a result we'll derive a coefficient, which will demonstrate country's movement to one or another direction in dynamics. Given this, the closer this coefficient to 0 , the higher position required country takes, approach to 1 means entering the pool of the worst countries by given indicator (Table 5).

Table 5 - Comparison of data of three ratings over the period from 2010 to 2014

\begin{tabular}{|l|c|c|c|c|c|c|}
\hline \multirow{2}{*}{ Rating name } & \multicolumn{5}{|c|}{ Years } & \multirow{2}{*}{$2010 / 2014$} \\
\cline { 2 - 6 } & 2010 & 2011 & 2012 & 2013 & 2014 & \\
\hline The rating of global competitiveness of World Economic Forum & 0,453 & 0,465 & 0,465 & 0,432 & 0,368 & 1,287 \\
\hline $\begin{array}{l}\text { The rating of global competitiveness of International Institute for } \\
\text { Management Development }\end{array}$ & 0,879 & 0,831 & 0,814 & 0,700 & 0,600 & 1,433 \\
\hline Doing Business of World Bank & 0,656 & 0,672 & 0,656 & 0,605 & 0,487 & 1,347 \\
\hline
\end{tabular}

Analysis of Table 5 allows concluding that over the analyzed period competitiveness of Russia in the world system of economic management has been increasing. Especially strong increase is observed in the rating of International Institute for Management Development: Russia thrust from 0,879 in 2010 to 0,600 in 2014 (increase in 1,43 times).

\section{Discussion and Results}

One of main tasks of our research is detection of degree of advantageous environment impact on the world market of 
hydrocarbons on increase in competitiveness of Russia. Is there and to what extent correlation between growth in competitiveness of Russia we revealed in the previous part and high prices for oil? What influence fall in oil prices from 110 to 60 doll./barrel will have on competitiveness of Russia and what impact economic sanctions imposed by the USA and its allies will have on competitiveness of Russia in general. In this context we carried out the analysis of such indicators as world oil prices, value of import to the RF and investment to fixed capital. We brought up an assumption that direct correlation between oil price and investment to fixed capital involves threatening impact of oil price downturn on competitiveness of the country, since elasticity coefficient of investment to fixed capital by income is more than 1.

To reduce the indicators of import to Russia and oil price to a common base we take 1994 as a starting point and correlate valued by years with the base period to detect growth as a percentage (Table 6).

Table 6 - Import to Russia and oil price (Brent) from 1994 to 2014

\begin{tabular}{|c|c|c|c|c|}
\hline Years & Import, USD mln & Changes, in \% by 1994 & Oil price per 1 barrel (Brent), USD & Changes, in \% by 1994 \\
\hline 1994 & 50452 & 100,00 & 15,8 & 100,00 \\
\hline 1995 & 62603 & 124,08 & 17,1 & 108,23 \\
\hline 1996 & 68092 & 134,96 & 20,5 & 129,75 \\
\hline 1997 & 71983 & 142,68 & 19,1 & 120,89 \\
\hline 1998 & 58015 & 114,99 & 12,7 & 80,38 \\
\hline 1999 & 39537 & 78,37 & 17,7 & 112,03 \\
\hline 2000 & 44862 & 88,92 & 28,3 & 179,11 \\
\hline 2001 & 53764 & 106,56 & 24,4 & 154,43 \\
\hline 2002 & 60966 & 120,84 & 25,0 & 158,23 \\
\hline 2003 & 76070 & 150,78 & 28,9 & 182,91 \\
\hline 2004 & 97382 & 193,02 & 38,3 & 242,41 \\
\hline 2005 & 123839 & 245,46 & 54,4 & 344,30 \\
\hline 2006 & 163187 & 323,45 & 65,4 & 413,92 \\
\hline 2007 & 223084 & 442,17 & 72,7 & 460,13 \\
\hline 2008 & 288673 & 572,17 & 97,7 & 618,35 \\
\hline 2009 & 183924 & 364,55 & 61,9 & 391,77 \\
\hline 2010 & 245680 & 486,96 & 79,6 & 503,80 \\
\hline 2011 & 318555 & 631,40 & 111,0 & 702,53 \\
\hline 2012 & 335771 & 665,53 & 121,4 & 768,35 \\
\hline 2013 & 341337 & 676,56 & 108,8 & 688,61 \\
\hline 2014 & 270055 & 535,27 & 98,9 & 625,95 \\
\hline
\end{tabular}

Ministry of Finance of the Russian Federation

Values given in Table 6 allow correlating in what way oil price influenced import consumption in Russia. Graphic presentation of these values is shown in Fig. 1.

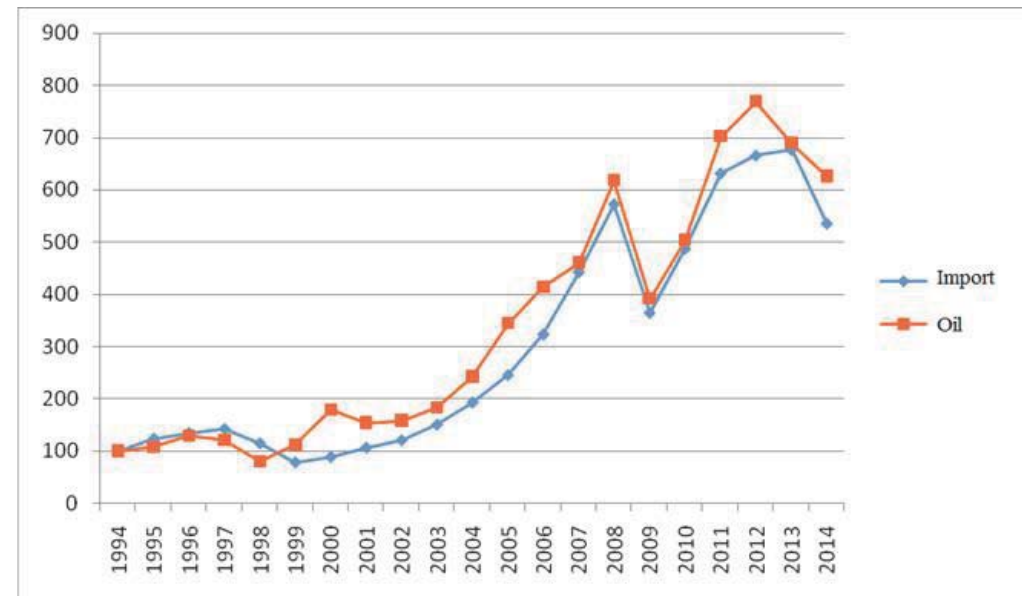

Figure 1 - Oil price and import to the RF in relative values to the level of 1994 
Dependence given in Fig.1 reflects direct correlation of import to the RF to oil price, that's why it is possible supposing that additional incomes, which economic agents earn for high prices for oil are committed not to extended reproduction of domestic goods and services, but expansion of high quality import consumption. In order to test out hypothesis regarding the correlation of oil prices, import value and investment to fixed capital we use data obtained from Table 6 and add numeric material on investment to fixed capital (Table 7). Calculation methods are the same (reducing to basic level and comparison of deviations (expressed as a percentage) in dynamics).

Table 7 - Investment to fixed capital, import to Russia, and oil price (Brent) from 2009 to 2014

\begin{tabular}{|c|c|c|c|c|c|c|c|c|c|}
\hline Years & $\begin{array}{c}\text { Investment to } \\
\text { fixed capital in } \\
\text { bln roub. }\end{array}$ & $\begin{array}{c}\text { Exchange } \\
\text { rate rouble/ } \\
\text { USD }\end{array}$ & $\begin{array}{c}\text { Investment to } \\
\text { fixed capital in } \\
\text { bln USD }\end{array}$ & $\begin{array}{c}\text { Changes, } \\
\text { in \% 2009 }\end{array}$ & $\begin{array}{c}\text { Import, } \\
\text { bln } \\
\text { USD }\end{array}$ & $\begin{array}{c}\text { Changes, } \\
\text { in \% 2009 }\end{array}$ & $\begin{array}{c}\text { Oil price per 1 } \\
\text { barrel (Brent), } \\
\text { USD }\end{array}$ & $\begin{array}{c}\text { Changes, } \\
\text { in \% } \\
2009\end{array}$ & $\begin{array}{c}\text { Investment to } \\
\text { fixed capital in } \\
\text { total imports, } \\
\%\end{array}$ \\
\hline 2009 & 7976,0 & 31,72 & 251,43 & 100,00 & 183,9 & 100,00 & 61,9 & 100,00 & 136,7 \\
\hline 2010 & 9152,1 & 30,37 & 301,36 & 119,86 & 245,7 & 133,58 & 79,6 & 128,59 & 122,7 \\
\hline 2011 & 11099,7 & 29,39 & 377,70 & 150,22 & 318,6 & 129,66 & 111,0 & 139,45 & 118,6 \\
\hline 2012 & 12586,1 & 31,09 & 404,79 & 161,00 & 335,8 & 105,40 & 121,4 & 109,37 & 120,5 \\
\hline 2013 & 13255,5 & 31,85 & 416,21 & 165,54 & 341,3 & 101,66 & 108,8 & 89,62 & 121,9 \\
\hline 2014 & 11536,5 & 41,24 & 279,72 & 111,25 & 270,1 & 79,12 & 98,9 & 90,90 & 103,6 \\
\hline
\end{tabular}

Ministry of Finance of the Russian Federation

Graphic presentation of these values is shown in Fig. 2.

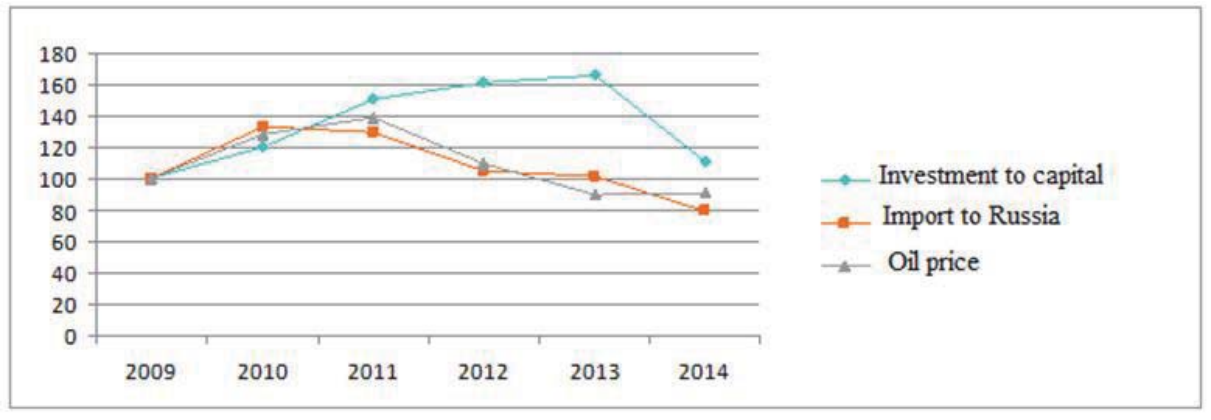

Figure 2 - Oil price and import to the RF and investment to fixed capital in relative values reduced to the level of 2009

The analysis of Table 7 Fig. 2 shows that investment to fixed capital weakly correlates to oil price and import to the RF, besides in 2012 and 2013 multidirectional dynamics was observed - oil price decreased, investment to fixed capital increased. Therefore, it's possible to state the following:

1) There's no correlation between prices for hydrocarbons and investment to fixed capital. It logically means that the more money the country receives as a result of export, the more it should invest into its development, if for no other reason than because monetary aggregate M1 is increased by additional incomes value. However, Russian practice shows that high prices for oil and other hydrocarbons have reverse of the coin. The more income is contributed to the budget from these recourses, the less structural reforms take place in economy, public administration quality begins to degrade, major government enterprises neglect cost saving and efficiency improvement, etc. that we've observed as a result of the analysis carried out;

2) There's direct correlation between oil price and number of consumed imported products and services in the $\mathrm{RF}$;

3) Global competitiveness of the country increased in the absence of external irritants for economy of the RF.

The conclusions we stated regarding competitiveness of Russia in short-term and medium-term periods would be fair before imposing sectoral and other sanctions in respect to Russia and subsequent negative tendencies in economy: devaluation of national currency, significant reduction of consumption, etc. Over the last months of 2014 and the past months of 2015 Russian economy from a slowing down one (1,3\% of GDP growth in 2013; 0,5\% - in 2014) has turned into a crisis one. Currently many economists (Glazev (2014), Ulukaev (2014) and others) give evidence of systemic crisis, 
the base of which is ineffective system of public and municipal administration. Sanctions in themselves and fall in prices for carbohydrates aren't the only culprits of existing crisis. It's one of prerequisites due to which it happened earlier than it had been expected. The base of modern crisis in Russia is an archaic structure of economy with dominance of nonefficient public sector, manual regulation at all levels of authority, large public expenditures in the area of defense industry and force structures, which have the minimum multiplier of investments as compared to other expenditures of federal budget.

In its turn, imposing sanctions and countersanctions in respect to Russia can be considered opportunities for the country. For example, currently much attention is given to the development of import substitution program. The results of our analysis showed that increase in prices for hydrocarbons is followed by expansion of import products consumption. The task of Government of the Russian Federation is to reallocate money flows and channel consumers' means both in b2c and b2b segments to domestic goods and services consumption. Effective implementation of the program will increase industrial production, strategic economic centers of innovations and priority development will be established, all that will increase population's income, etc. Branches defined as priority ones for import substitution: equipment for food industry, heavy engineering industry, power engineering industry, electrochemical and cable industry, oil-and-gas machine building, tool-making industry, ship-building equipment (shipboard accessory equipment), radioelectronics industry, chemical and petrochemical industry (catalysts, production of rare earth materials, composition materials, paints and polishes, plastics, production of detergent, cleaning, and polish agents, as well as products made of rubber and plastics), pharmaceutical industry, medical industry, conventional weapons industry, civil aircraft industry, engine-building, components and equipment for transport machine building.

Programs of import substitution by branches should be supported with targeted funding. Accordingly, it's important to relevant ministries and departments to choose correct projects' selection criteria. One of main selection parameters is to substitute foreign products of investment purpose. Other important criteria are the following: an investor should provide not less than 20\% from own funds for project financing, a project should be under Russian jurisdiction, participation of organizations under off-shore jurisdictions isn't allowed. Only project financing on the part of a non-resident company under individual free-standing agreement with development institute is acceptable. A project should be focused on establishing manufacturing, import ratio of which in Russia is from 80 to $100 \%$. It should provide development of production of nodes and components, which will substitute foreign ones or corresponding share of exports subsequent to the results of project execution should make up not less than $20 \%$ of general output of product range. Project implementation period (exploitation stage beginning) should be no more than three years. Export-oriented project payback period should be no more than 7 years, import substitution project - no more than 10 years.

Program data will be developed for each of priority import substitution areas. The Ministry of Energy of the Russian Federation valuated import substitution expenditures of oil and gas companies to 2020 at 8-10 bln. roubles (130-167 USD $\mathrm{mln}$.). According to investment data by 2020 the RF will be able to substitute horizontal drilling and hydrofracturing technologies, hard-to-recover reserves technologies, offshore projects and liquefied natural gas projects equipment. Companies, which will carry out these developments are specified: Rosneft JSC, Gazprom JSC, Gazprom neft JSC, SIBUR JSC, LUKOIL JSC, Surgutneftegaz JSC. These companies are responsible for particular technologic directions, currently they start the work by realization of import substitution possibility for three planning horizons - until 2016, 2018 and 2020 years.

\section{Conclusions}

As a result of carried out research the following conclusions can be drawn:

1. Main causes of poor competitiveness and deterioration of major social and economic indicators of Russia at the beginning of the $90 \mathrm{~s}$ of the $20^{\text {th }}$ century are the following: accelerated liberalization and privatization according to recipes of IMF; destruction of science; from 1992 shift to humanitarian system of economists' training, managers training using Western textbooks detached from Russian reality; waiving strategic planning institute at all levels of management; the absence of transitional economy theory; governmental waiving development of complex strategy of country shift to market relations and problem strategies over a long-term perspective; very slow implementation of strategic marketing conception and activity focus on competitiveness of objects under regulation into the system of higher education; low quality of management decisions,

2. Over 20 years the structure of economy and the level of competitiveness of the country have undergone major changes. The level of global competitiveness according to the ratings of World Economic Forum and International Institute for Management Development has significantly increased over the last years. According to the business activity rating - Doing Business - results of 2014 of Russia are the best over the record 
history.

3. Based on extrapolation methods - trend analysis - the conclusion is made that the level of competitiveness of Russia would increase in years to come in the absence of strong external irritants.

4. Influence of oil prices on the fundamental components of Russian economy is considerably exaggerated, since increase in oil prices leads to directly proportional increase in imports. While it was revealed there is no direct correlation between prices for hydrocarbons and investment to fixed capital.

5. Currently Russia has 3 variants of development: negative, neutral and optimistic. According to our research negative outcome will be most probable if the system of public municipal administration won't be changed qualitatively; cooperation economic relations with western countries won't be restored; the structure of economy won't be changed: dominance of public sector over small and medium private business; approach in relation to public expenditures won't be changed; areas that have maximum multiplier of investments for economy, such as education, science and healthcare will be reduced and those that have low investment effect - will be increased: defensive, law and order expenditures, and others.; import substitution program won't be implemented in Russian economy to the full extent, etc. Following neutral and optimistic forecasts depends on the fulfillments of conditions listed in the negative forecast.

\section{References}

Azoev, G. (2002). Competition: analysis of its strategy and practice. In G.L. Azoev. MA: Center for Economics and Marketing, 208 p.

Baumgarten, L. (2005). Analysis methods for determining the competitiveness of companies and products. Marketing in Russia and abroad, 4 (48), pp. 72-85.

Bogomolov, I. (2005). Analysis of the formation of categories of competitiveness as a factor of economic superiority of market facilities. Marketing in Russia and Abroad, 1 (45), pp. 113-119.

Doing Business database. (2014). Retrieved from: http://www.doingbusiness.org/rankings

Drucker, P. (1981). Toward the next economics and other essays.

Fedorenko, N. (2001). Russia: lessons from the past and faces the future. Moscow: Economics, $490 \mathrm{p}$.

Fisher, I. (1906). The nature of capital and income.

Galbraith, J. (1975). Money: whence it came, where it went.

Gelvanovsky, M. (1998). Competitiveness of micro, meso macro-level dimensions. Russian Economic Journal, 3, pp. 67-68.

Goncharov, N. (1998). Marketing innovation process: Proc. Manual. 267 p.

IMD World Competitiveness Yearbooks, 2009-2014. (2014). Retrieved from: http://www.imd.org/wcc/wcy-world-competitivenessyearbookl

Iwaniec, V. (2000). Macrotechnologies and ensuring the competitiveness of domestic industry. Industry of Russia, pp. 25-32.

Keynes, J. (1919). The economic consequences of the peace.

Krugman, P. (1999). The spatial economy: Cities, regions and international trade.

Lifits, I. (2004). Formation and evaluation of the competitiveness of goods and services. MM: Yurayt-Izdat, $335 \mathrm{p}$.

Lindert, P. (1986). International Economics.

Litvinenko, V. (1993). Methods to ensure the competitiveness of products. Standards and Quality, 8, pp. 23-28.

Lvov, D. (2001). Institutional economics. Moscow: Infra, 318 p.

Mansurov, R. (2006). On the economic substance of the terms "enterprise competitiveness" and "management of enterprise competitiveness". Marketing in Russia and Abroad, 2 (25), pp. 91-94.

Marshall, A. (1879). The pure theory of foreign trade and the pure theory of domestic values.

McConnell, C., Brue, S., \& Flynn, S. (2014). Economics: Principles, problems, \& policies.

Mill, J. (1848). The Principles of Political Economy: with some of their applications to social philosophy.

Ministry of Finance of the Russian Federation. (2015). Retrieved from: http://info.minfin.ru

Ostrovsky, G. (2001). Competitiveness of the enterprise as an object of management. Consultant Director, 20, pp. 34-36.

Porter, M. (1990). Competitive advantage of nations. New York: Free Press.

Ricardo, D. (1817). On the principles of political economy and taxation.

Rogoff, K. (2009). This time is different: Eight centuries of financial folly.

Schumpeter, J. (1934). The theory of economic development: an inquiry into profits, capital, credit, interest, and the business cycle. New Brunswick, New Jersey: Transaction Books. Translated from the 1911 original German, Theorie der wirtschaftlichen Entwicklung.

Seleznev, A. (1999). Competitive position and market infrastructure in Russia. Moscow: Jurist, 384 p.

Shekhovtseva, L. (2001). Competitiveness of the region: factors and methods for creating. Marketing in Russia and abroad, 4, pp. 11-15.

Sinko, V. (2001). The competitive environment needed to produce competitive products. Standards and Quality, 6, pp. 38-42.

Smith, A. (1776). An inquiry into the nature and causes of the wealth of nations.

Solow, R. (1956). A contribution to the theory of economic growth. Quarterly Journal of Economics (The MIT Press) 70 (1), pp. 65-94.

The systemic crisis in the economy. (2014). Retrieved from: http://cont.ws/post/66139

Voronov, A. (2000). To assess the level of competitiveness of machine-building enterprises. Mashinostroitel, 12, pp. 27-29. 
Vorotnikov, A. (2001). Strategy for improving the competitiveness of the region. Economic strategy, pp. 144-149.

WEF Global Competitiveness Reports, 2009-2014. (2014). Retrieved from: http://www.weforum.org/reports

Williamson, J. (1989). Globalization: the concept, causes, and consequences.

Yanovsky, A. (1997). Competitive products and manufacturer of products in the market economy system. Standards and Quality. No. 2, pp. 43-44.

Yudanov, A. (1996). Competition: Theory and practice: Proc. manual for schools. MM: Akalis, 272 p.

Zakharchenko, V. (1999). Evaluation and analysis of the competitiveness of enterprises. Mashinostroitel, 11, pp. 13-17. 
ISSN 2039-2117 (online) ISSN 2039-9340 (print)
Mediterranean Journal of Social Sciences MCSER Publishing, Rome-Italy
Vol 6 No $3 \mathrm{~S} 3$ May 2015 